\title{
ENVISIONING THE ART OF EMPIRE IN THE LETTER OF ARISTEAS
}

\author{
Max Leventhal $\star^{+}$ \\ Downing College, Cambridge, UK \\ ^Corresponding author. Email: ml649@cam.ac.uk
}

This article examines two 'digressions' within the Letter of Aristeas: the description of the gifts which Ptolemy sends to the Jerusalem Temple (\$\$5I-82) and the survey of the Jerusalem Temple, the city and the Judaean countryside, including the final comments on Persian mining on the Arabian border ( $\left.\$ 8_{3}-120\right)$. I propose that Aristeas envisions the Alexandrian artworks as an imperial subject and that, by juxtaposing the two passages, he comments on the imperial machinations that attend the production of artworks. In concluding I suggest that this anxiety about material cultural production in an imperial context has ramifications for the Letter's central narrative of literary cultural production: the Alexandrian creation of the Septuagint.

\section{Introduction: viewing subjects}

Art is power. Modern scholars of Greek and Roman antiquity know this well and are particularly adept at identifying, interpreting and contextualising the configuration of elements in visual media that cohere to transmit an image of authority. Studies abound that trace how art asserts the legitimacy of power and can coax the powerless to acquiesce to control. Yet it is much more difficult to discern how images were received. What did subjects of empires actually think about specific artworks, about how and whether they served imperial interests and about the nature of art as a medium for exercising power more widely? And how could subjects express an awareness, anxiety or even critique about the art of empire in their subordinate position under the hegemony of others?

Such 'views from below' are sparse in the historical record. However, the situation of the Jewish diaspora in Hellenistic Egypt constitutes a distinct vantage point. Jews were classified as Hellenes ('Greeks') in Ptolemaic fiscal and legal matters and some were even 'part of the

\footnotetext{
II am grateful to Albert Bates, Thomas Nelson, Mike Squire, Helen Van Noorden and Tim Whitmarsh for discussing the article with me at various stages during its development. I also wish to thank the anonymous referees for their helpful guidance. All errors remain my own.
} 
privileged minority of foreigners who served the king'. ${ }^{\mathrm{I}}$ Nevertheless, the Ptolemaic state was controlled by the Macedonian royal family and its representatives: the Jewish position as a privileged group rested precariously on the whim of those in power. 3 Maccabees sharply delineates that sense of precarity. Not only does Ptolemy IV Philopator give the Jews an ultimatum that they may keep their civic rights only if they are initiated into the mysteries (3 Macc 2:30), but their collective existence depends on this fickle king who repeatedly forgets when sober the decisions made while drunk and vice versa (3 Macc 5:15-21, 27-33, $3^{6-42}$ ) and whose 'unstable mind' ( close kinsmen. Philo's In Flaccum and Legatio ad Gaium make patent that centuries later their status had to be renegotiated and reaffirmed with the new ruling power, once Egypt had become a Roman province. The Jewish diaspora in Egypt participated in the hegemonic Greek culture but undoubtedly also held the perspective of imperial subjects.

I propose here that the Letter of Aristeas (henceforth, Letter) is a sophisticated but much under-appreciated Hellenistic Jewish text specifically documenting a subaltern view of imperial art. The Letter is a rare, fully preserved example of literary prose from Hellenistic Alexandria. It purports to be an eyewitness account of the events surrounding the translation of the Hebrew Torah into Greek, executed at the order of King Ptolemy Philadelphus sometime in the early third century BCE. The narrator and main character Aristeas describes how he led the embassy to Jerusalem in order to obtain the Torah scrolls and seventy-two translators from the high priest Eleazar, then escorted them to Alexandria where they carried out the translation and created the Septuagint. Interleaved with Aristeas' account of the events surrounding the translation are several so-called 'digressions'. ${ }^{2}$ I will be focusing on Aristeas' description of the gifts which Ptolemy sends to the Jerusalem Temple $\left(\$ 5_{5}-82\right)$ and his survey of the Jerusalem Temple, the city and the Judaean countryside, including his final comments on Persian mining on the Arabian border ( $\$ \$ 83-120){ }^{3}$

Although this narrator presents himself as an Alexandrian court official and claims autopsy, several features of the text make it clear that it was composed in the late-second century BCE. ${ }^{4}$ More importantly, the author of the Letter is undoubtedly Jewish. ${ }^{5}$ This means that the description of the Alexandrian art gifted to the Temple and the depiction of Jerusalem, its Temple and the Judaean countryside are written from the perspective of a Jew living in Alexandria under Greek rule. My claim here is that underneath the veneer

I Honigman (2016) 50. For Jews as Hellenes for tax purposes see Modrzejewski (I993) 79-80, (I997) 73-83 and Clarysse and Thompson (2006) 2.138-48, and for their legal status Segré (I944), Modrzejewski (I997) II2-I9 and Honigman (2003a).

2 This is a traditional and persistent term for the passages; cf. Février (I924) 22-3I; Meecham (I932) 2IO-I8; Hadas (195I) 1959; Honigman (2003b) passim; Wright (2015) 55-6.

3 The other 'digressions' are the high priest Eleazar's exegesis of the Jewish Law (\$§I28-7I) and the seven symposia at which Ptolemy questions each of the Judaean translators (\$\$I87-300). The Greek comes from Pelletier (I962) with the chapters referred to by section sign (\$). My translation adapts Hadas (I95I).

4 Modern consensus places the Letter during the latter half of the second century BCE; Wright (20I5) 2I-30. I am persuaded by Moore (2015) 210-I3 and White and Keddie (2018) 34-8 that the later end of that range is most likely.

5 The narrator's comments are in keeping with the opinions of a Hellenistic Jew rather than those of a non-Jewish Alexandrian courtier; cf. Jellicoe (I968) 30-5; Wright (2015) 6-I5. 
of an account written up by an Alexandrian viewer working for the Ptolemaic court there lies a description filled with all the anxiety of a viewing, imperial subject. This non-hegemonic perspective emerges, I suggest, when the depiction of the Alexandrian gifts is set against the survey of Jerusalem and the Judaean countryside. The present article traces out two ways in which that juxtaposition comments on the imperial machinations that attend the production of artworks.

The two 'digressions' are connected thematically since they both direct the reader's gaze towards nature: the gifts are decorated with several floral motifs while the account of Judaea emphasises the cultivation of the land. In the first section, I look at the emphasis on artistic naturalism in the description of the gifts and contrast this with the subsequent account of the Jerusalem Temple and the cultivation of Judaea. I then focus on how this contrast is made explicit when Aristeas compares Judaea's and Alexandria's agricultural economy. This will reveal an author who associates the imperial display of power through simulations of nature with a form of luxury that requires and produces economic inequality and civic disequilibrium. In the second section, I examine the brief mention of Persian mining that formerly threatened Judaea and I connect this back to the gifts and the artisans' crafting of nature out of precious metals. I argue that, while the author appeals to a Ptolemaic discourse of mining and the fashioning of luxury items from precious metals, he also places this process of artistic materialisation in an imperial light. From a Jewish perspective, an interest in crafted precious metals and stones cannot be separated from the exploitation of natural resources through which such materials are acquired.

Thus, while studies generally assume the Letter and the description of the gifts to be 'proAlexandrian' in orientation, this article contends that the two passages from Aristeas' embassy offer a complex and critical account of how nature, art and power interrelate. In short, the depiction of the gifts together with the Judaean land envisions the art of empire.

\section{Nature, art and artifice}

I begin with the gifts that Ptolemy is said to have donated to the Jerusalem Temple. They comprise a table of the showbread $\left(\$_{5} \mathrm{I}-72\right)$ - a piece of furniture set in the Temple always in the presence of God and bearing twelve loaves of bread - and two gold and two silver bowls used as part of the Temple liturgy $(\$ \$ 73-82)$. The recurring decorative scheme upon the table and the vessels consists of various fruits, crops and plants. Here is a representative example from the table:

Beneath the raised pattern of the egg-design made of stone, the craftsmen made a garland of various fruits; clearly visible on the projection were grape clusters and corn ears and dates and apples, an olive tree and pomegranates and the like. Having worked the stone into the full shape of the aforementioned fruits, which had the colour of their particular species, they tied them onto the gold circle around the whole construction of the table at the sides. (\$63) 
The gifts' design would have made sense to its Hellenistic audience: all the vegetation represented on Ptolemy's gifts can be paralleled in the contemporary material remains from the land of Israel and these same motifs can be paralleled in the Greek art of the period. ${ }^{6}$ Equally, the choice to elaborate on this design is a conscious one. The gifts are described with a scriptural model in mind. The Letter mentions the table's 'twisted moulding' decoration ( $\sigma \tau \rho \varepsilon \pi \tau \grave{\alpha} \kappa \nu \mu \alpha \dot{\tau} \tau \alpha$, \$58), a phrase which is paralleled only by Exodus' identical phrasing in its description of the table of the showbread (LXX Exod 25:24). ${ }^{7}$ However, Exodus' account of the showbread and of the vessels is devoid of any floral motifs (cf. LXX Exod 25:22-9), although such a design is found, for example, in the immediately following prescription that the decorations on the menorah be like a flower bud or lily (LXX Exod 25:32). The floral decorations are thus an Alexandrian addition to the table of the showbread, albeit in a Greek style that matches up with the local visual style in Jerusalem and one in line with the general prescriptions for the Tabernacle furniture in Exodus.

More than simply being a decorative style in the spirit of the Exodus description, however, the Letter makes the scheme a specific point of aesthetic interest. Aristeas' description above (\$63) of the floral design highlights the table's workmanship and details the process by which the craftsmen created the vision and transformed the raw material into a simulation of fruit and its variety of colours. Elsewhere he describes how they constructed ivy woven

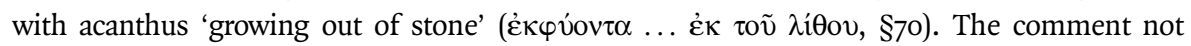
only underscores the craftsmen's ability to produce a likeness of the vitality of nature; it suggests that the execution is so realistic that the ivy looks rather to be escaping or growing from the very medium that gives it form. By far the most significant articulation of the Alexandrian artists' skills is Aristeas' detailing of the table legs' construction:

The arrangement of the four legs was the same, everything being made and brought together effectively; with respect to the pre-eminence of experience and skill it was indistinguishable from the truth so much that if there was even a gust of wind in the air the arrangement of the leaves allowed for movement (

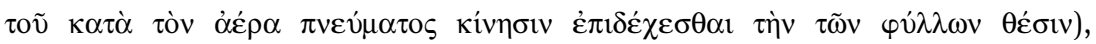

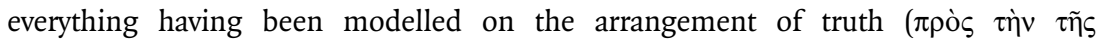
$\dot{\alpha} \lambda \eta \theta \varepsilon i \alpha_{\varsigma} \delta$ ió $\left.\theta \varepsilon \sigma \mathrm{v}\right)$. (\$70)

This passage invokes the abiding criterion of naturalism in Greek art-critical discussions, namely a work's correspondence to truth $(\dot{\eta} \dot{\alpha} \lambda \dot{\eta} \theta \varepsilon 1 \alpha) .{ }^{8}$ Aristeas expresses the sheer persuasiveness of the craftsmen's ivy despite it being manifestly carved from stone. The proximity to truth here is aided by the fact that the leaves are sufficiently light and

6 For the Jewish material see Hachlili (1988) 79-8o, and for the Greek see Heath (2013) 39-43 and Wright (2015) I857.

7 Septuagint quotations are from Hanhart and Rahlfs (2006) and the translations are adapted from Pietersma and Wright (2007).

8 Cf. e.g. Pollitt (1974) I25-73. 
flexible to move with the breeze, a technique that again finds parallels in the material remains of the period. ${ }^{9}$

Aristeas' appreciation of this exquisite craftsmanship and its adherence to truth fits within a wider Hellenistic literary habit of having internal audiences praise works of art and appeal to similar critical terminology. Theocritus famously has Praxinoa admire the woven tapestries put on display for a festival of Adonis and exclaim how the images look alive (Id. 15.82-3), and Herodas similarly has his female characters respond in awe to lifelike statues (Mim. 4.37-8). ${ }^{\text {ro }}$ Likewise, the numerous epigrams praising Myron's realistic statue of a cow repeatedly highlight the extent of its naturalism. ${ }^{\text {II }}$ Yet if Aristeas' viewing mobilises this literary trope, then it also, as Heath observes, adapts it to Jewish sensibilities. ${ }^{\text {I2 }}$ It is typical for viewers of art to imagine that the statue or image might be

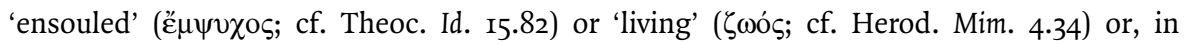
the case of Myron's cow, 'full of breath', 'with the breath of life' (ع̋ $\mu \pi v o o s ;$ cf. Anth. Pal.

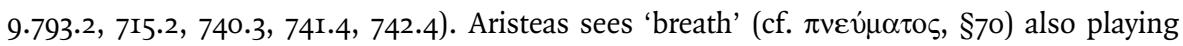
its part in suggesting the persuasiveness of the simulation of nature, but it does so as the wind which rustles the leaves. This most likely responds to Jewish conceptions of visual representation as set out in the Second Commandment (LXX Exodus 20:4; cf. Deut 5:8). This commandment has a long interpretative history which does not permit a coherent picture, but the surviving evidence does suggest that the central issue in Hellenistic Judaism was the rejection of idol worship in particular. ${ }^{\mathrm{I} 3}$ The representation of plants and vegetation is therefore best taken as a matter of intercultural diplomacy as far as Ptolemy's construction of the gifts is concerned, above anything specifically theological; the decoration avoids any living, breathing creature which could be interpreted as idolatrous. Aristeas' appraisal of the lifelikeness of the plant life on the gifts is a concerted adaptation of a Greek trope to the new context of Jewish traditions of visual representation.

The craftsmanship of Alexandrian art and its ability to capture nature in material form ought also to be juxtaposed with Aristeas' subsequent and equally visual description of the Judaean countryside and the Jerusalem Temple. The city of Jerusalem is well proportioned, the countryside is large with considerable variation in terrain and, though this means it requires continuous agricultural attention, it is this very care which generates the

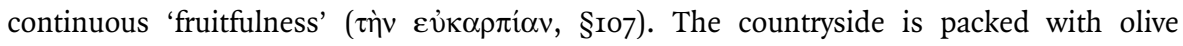
trees, cereal crops, pulses, vines, date palms and many other fruit trees (SII2). Equally,

9

IO

II

I2

I3

Cf. Heath (2013) 42-3 for Hellenistic gold-leaf.

For discussion of both scenes cf. e.g. Goldhill (I994); Zanker (2004); Männlein-Robert (2007) ch. 7.

Squire (2010).

Heath (2013) 42-4.

Throughout antiquity both a stringent ban on any visual representation and an emphasis instead on idolatry only have been operative. Unsurprisingly, there is a large bibliography here. I have found the following useful: Gutmann (I96I) and (1977) on the Deuteronomic context; Levine (2012) on Late Antiquity; Neis (2013) ch. 5 on the rabbinic viewing of idols; and the range of perspectives in Pearce (2013). von Ehrenkrook (20II) chs. 2-3 is particularly clear. On the Hellenistic Jewish context cf. Fine (2005) 69-73 and Levine (20I2) 3I. 


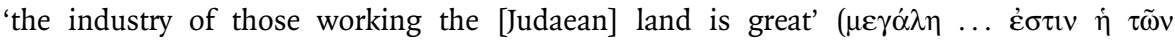

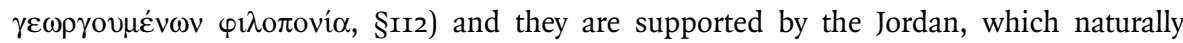
irrigates the land (§II6) and contributes to the abundance (\$II5). Such a symbiosis is presented also from a different angle, in that Judaean fertility enables Jerusalem and Judaea to cope with a 'large populace' ( $\pi$ o $\lambda v \alpha v \theta \rho \omega \pi i \alpha$, §II3). The fact that the land 'was no less than 60 million measures of land ... and 600,000 men have roo land-measure lots' (§II6) recalls the number of those who left Egypt with Moses to settle in the land (LXX Ex I2:37; Num II:2I), but it also gives detail to the claim of $\pi \mathrm{o} \lambda v \alpha v \theta \rho \omega \pi i \alpha$ and of the proportional distribution of people. The Jewish population and agriculture are thoughtfully balanced, and such distribution has a basis in Jewish historical records. The Judaean land is perfectly organised for commerce as well as agricultural abundance, which is reflected in its infrastructure. There is an import of 'a great amount of spices and precious stones and gold', the country is constructed 'to be worked and with an eye

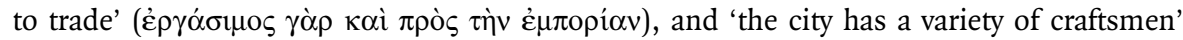

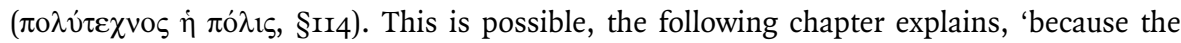
land has convenient and abundantly furnished harbours' (§II5). The arrangement of Judaea produces not only natural goods, but also a context in which crafts and luxury trade can flourish.

At the heart of Judaea is the city and at the heart of the city is the Temple, a manufactured space that is nevertheless integrated into the land and the natural economy. The priests make offerings in the Temple of those same products in which the country is rich: wood, olive oil, wheat flour and cattle (\$92). Likewise, there is an implied natural continuity with the 'ever-flowing' ('́xíppovs) river Jordan that 'flows around' ( $\pi \varepsilon \rho \rho \rho \varepsilon \tilde{\imath}, \S \amalg 16)$ the land and the water source of the Temple that is both 'unceasing'

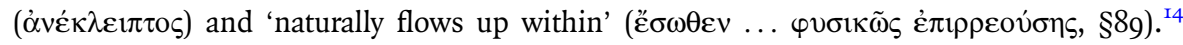
When precious stones and metals are employed they are used for the furnishing of the high priest's garment, on which are twelve stones representing the twelve tribes of Israel. In contrast with the stones on the table that varied in simulation of different fruits $\left(\$ \sigma_{3}\right.$, above), each of these stones 'flashes forth the indescribable natural colour of its particular essence' (\$97): their naturalness qua stones produces an aesthetic effect worthy

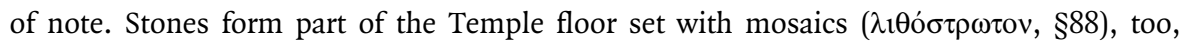
and they are used to ensure the smooth running of the liturgy and for the cleaning away of the blood from the sacrifices. Stone, water, natural produce and livestock all function in the Temple as part of the essential administration of the sacrifices and the worship of God. At the heart of Judaea sit the Temple and the high priest's robes, yet the ability for this site to function as the centre of the Jewish state is only possible through the interaction of the manufactured and the natural. The Temple's holiness and importance come from the continuous and unceasing sacrifice in it, and this relies on a continually

I4 The descriptions of the reservoirs servicing the Temple with their 'streams' ( $\tau \tilde{\omega} v \dot{\rho} \varepsilon v \mu \alpha \dot{\tau} \tau \nu$, §89) and of the

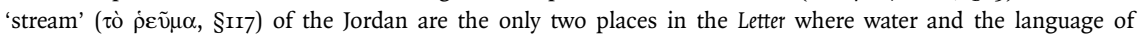
flowing occur. 
productive land. In the Letter, a balanced symbiosis between the land, the people and this particular constructed object is essential for the Jewish liturgy in Jerusalem. In contrast to the craftsmanship of the gifts and their capturing of nature in art, the description of the Judaean countryside and the Jerusalem Temple emphasises a distribution of labour to the cultivation of natural products and to the construction of objects that aims to benefit the entire populace.

Moreover, the difference between the two cultures with respect to the working of the land and the distribution of labour is made explicit by Aristeas when he turns to contrasting Jerusalem, whose founders 'constructed the city with appropriate proportion

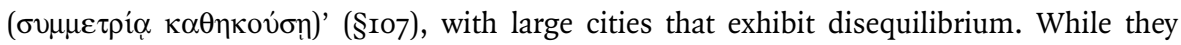
may have prosperity, they also happen to be 'well populated, but neglect the countryside'

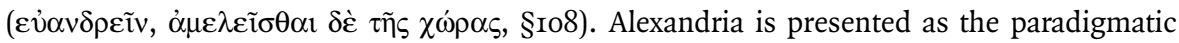
case. Whereas the tradition in the Alexander Romance explicitly notes that it avoided disequilibrium because of the measured planning of its architect Deinocrates (I.3I.6-7), the Letter explains that due to the delights of Alexandria, those from the country remain

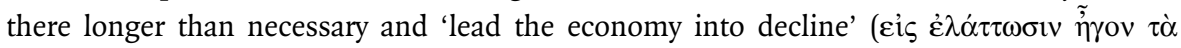

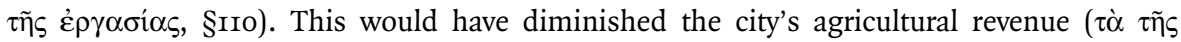
$\gamma \varepsilon \omega \rho \gamma i \alpha \varsigma \pi \rho o ́ \sigma \varphi \rho \rho \alpha)$ had Ptolemy not stepped in to reduce farmers' maximum sojourn in the city (SIII). In contrast to the Judaean balance between city and chōra which was established for the populace from its very beginnings and which continues naturally and in perpetuity without need of correction, Alexandria operates with an unstable equilibrium which requires top-down intervention in the present despite being a recently founded city. Strikingly, Aristeas chooses to focus on the farmers in each case: those who most ought to be taking advantage of and working with the natural abundance of the Egyptian land are precisely those whom the prosperous capital draws away from their work and concentrates in the city. An overabundance of wealth is difficult to square with a well-distributed attendance to a country's natural resources and fecundity.

The intense, highly concentrated nature of Alexandria is an enduring aspect of the city's image in antiquity. ${ }^{15}$ Theocritus' Idyll $I 7$ is an important precursor for the theme of Egypt's natural fertility and its concentration of wealth. In his encomium of Ptolemy Philadelphus he lauds the richness of Egypt and Ptolemy's control over its borders. The flooding of the Nile means that 'no land is as productive as low-lying Egypt' (79-80) and the land supports no fewer than 33,333 'cities' $(82-5){ }^{16}$ The rewards of this control and fecundity are in turn reaped by Ptolemy - for whom every day great wealth is added 'to his rich store from

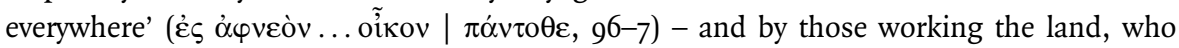

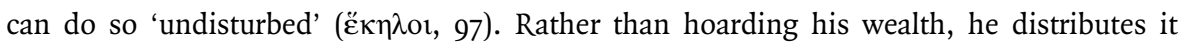
as gifts for temples, for other monarchs and for various Hellenistic city states (IO8-II). This depiction also very probably draws on Egyptian traditions of kingship: Richard

I5 Cf. Strabo I7.I3 and Dio Chrys. Or. 32.36, with Hunter (20II) 49-50.

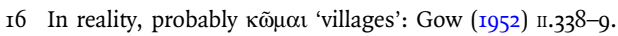


Hunter has demonstrated through comparative material that the image of Ptolemy amassing and bestowing wealth and securing Egypt has a long tradition in pharaonic representations of royal responsibilities. ${ }^{17}$ Quite differently from the image in the Letter, then, Theocritus presents a Ptolemaic and Egyptian perspective where the richness of the land and the concentrated wealth of the city go hand in hand; Ptolemy is the central, imperial power able to redistribute resources to the benefit of everyone and to preserve a land that can be peacefully cultivated.

This Ptolemaic ideology of Egyptian riches and fertility was also set on display within Alexandria. Callixeinus of Rhodes' About Alexandria, commonly dated to the mid-second century BCE, records Philadelphus' large procession as part of an international festival and the pavilion erected at the heart of the city during it. ${ }^{18}$ The pavilion, stuffed with hundreds of tripods, couches, carpets, curtains and statues (Ath. 5.196b-e, r97a-b), would have sent a clear message about Ptolemy's wealth and the lavishing of it upon his subjects, while the releasing of birds into the procession with wool ribbon attached so that they might easily be caught by the spectators (Ath. 5.200c) and a 3,000-amphora wineskin emptied along the parade route flooding it with wine (Ath. 5.19gb) make for an unmistakable sense of fertile excess. The event highlights the lengths to which the Ptolemies could go to advertise their territory's fecundity and their amassed wealth.

Moreover, although Callixeinus was most likely not an eye-witness, he attests to a later impression that this image of empire is highly stage-managed. The pavilion was strewn with flowers from every season, a combination only possible because of Egypt's particularly temperate climate (Ath. 5.196d-e). This made it appear like a divine meadow and, because the event took place in mid-winter, 'the appearance of the reception was contrary to the expectations ( $\pi \alpha \rho \alpha \dot{\delta} \delta \xi_{o} \varsigma \dot{\eta} \varphi \alpha v \tau \alpha \sigma i \alpha$ ) of the guests' (Ath. 5.196e). A vast amount of natural resources has been devoted to visual manipulation, and this is not an isolated case. Ptolemy Philopator reportedly attempted to trick the Stoic Sphaerus with wax pomegranates, hoping to fool him into assenting to the proposition of their being real despite the philosopher's avowal that certainty can be derived from empirical evidence (Diog. Laert. 7.177). Likewise Antigonus Doson claimed that Aratus of Sicyon returned to his allyship after 'having seen that everything in Egypt is play-acting ( $\tau \rho \alpha \gamma \omega \delta i \alpha v)$ and

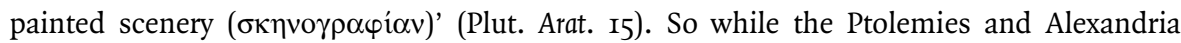
were famed for their accumulated wealth and fertile lands, there also existed a sense that these substantial resources were directed towards exercising imperial power through simulations of the real and spectacles of artificiality. ${ }^{\text {19 }}$

Within the Letter, however, Alexandrian accumulation and artificiality are presented from a Jewish perspective, with Judaean activities as a point of contrast. On the one hand, the Letter claims all the agricultural fecundity for Judaea that might typically be associated

I7 See the various comments through Hunter (2003) I56-82.

I8 Cf. Rice (1983) I64-7I and Keyser (2014) for discussion.

I9 For further artistic context cf. Webster (I967) 66. Cf. Platt (2009), who argues similarly for the dual illusionistic and political import of (paradoxical) renderings of vegetation in Augustan art. 
with descriptions of Alexandria, while all that Alexandria is seen to produce is an artistic simulacrum of nature. Notably, the flora depicted on the table corresponds to the fertile produce of the Judaean land. The olives trees are matched in the decorations of the table ( $\left(I I 2\right.$; cf. $\$ 6_{3}$ and 79), as are vines (\$\$6o and 79), date palms (\$63) and, more generally,

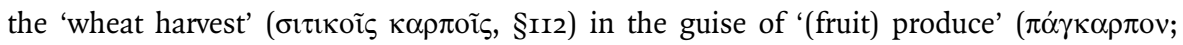

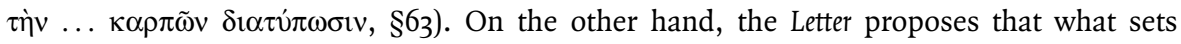
Jerusalem apart from Alexandria in their handling of natural fertility is their distribution of labour and capital. The diligence devoted to the two sorts of products is identical: those working the Judaean land possess 'great industry' ( $\varphi 1 \lambda_{0} \pi$ oví $\alpha$, $\S_{I I 2}$ ) and the

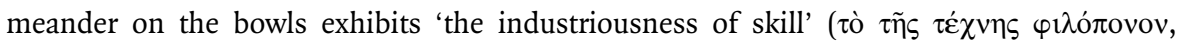
\$74). Yet central investment highlights the differing priorities of Alexandria and Jerusalem. Both projects receive generous funding, but whereas the 'convenient well-

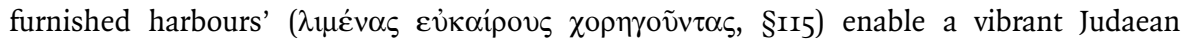
commerce, Ptolemy concentrates unparalleled wealth into the gifts as well as his own attention, with the result that he would even neglect public business (\$\$80-2). Where

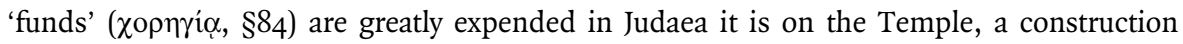
which I have suggested is fully integrated within the land's economy and the state's theological commitments.

Not only does the gifts' vegetal scheme represent Alexandrian art's naturalist pretensions, then, but the excessive cost and labour poured into manufacturing such refined artifice connects to a wider Alexandrian pattern of unstable economic and agricultural distribution. In fact the luxury of the gifts will have a similar effect for subsequent viewers: just as farmers spent too long in Alexandria because of its delights and Ptolemy devotes all his resources to the gifts' construction, so those who view the alternating arrangement of the gold and silver bowls 'were unable to tear themselves away

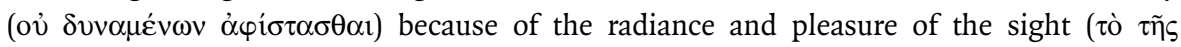

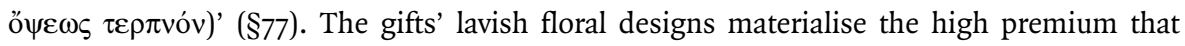
Ptolemaic politics places on simulations of nature over and above the natural cultivation of the land, and the visual effect of the bowls underscores just how arresting and disruptive Alexandrian art can be. The artifice of nature and display of wealth concentrated within Ptolemy's gifts are anathema to Jerusalem's civic and agricultural proportionality.

\section{Materiality, mining and domination}

It is the material from which the gifts are made that enables Ptolemy to concentrate so much wealth within their design as well as to create an impressive visual effect. The stones and their craftsmanship are worth five times as much as gold (\$82) and ivy seems to literally grow out of the stone $(\$ 70)$ : quite different from the functional use of stones in the Temple (\$88; see above). Again Callixeinus provides roughly contemporary comparative material: the recurring visual strategies in both the pavilion and the procession are 
artificial representations of nature (Ath. 5.196c, I97e-f) and the use of precious stones and metals (Ath. 5.197b, I99c). Given the importance of these high-value materials, it is significant that Aristeas' account of his embassy concludes with a rather different interrelation, from an imperial perspective, between precious metals and the countryside, in a passage that has been almost entirely overlooked: ${ }^{20}$

(§II9) It is also said that formerly mines of gold and iron were established in the mountains lying before Arabia. These had been deserted at the time when the Persians ruled, because at that time those in charge concocted a false story that the working of them was useless and very expensive, (\$I2O) so that the country would not be destroyed on account of the mining of the aforementioned materials and almost be alienated on account of their [i.e. the Persians'] domination, taking this as a pretext for entering these places. Because of which, this false report came about.

Aristeas recalls the historical Persian domination of Judaea and the Persians' desire to gain possession of its naturally endowed resources. The brief narrative, and especially \$I20, outlines the interconnected imperial interests of territorial expansion, exploitation of the land, and acquisition of luxury goods and materials. These concluding comments demonstrate an awareness that an imperial economy of luxury materials could literally undermine a Jewish hold on the land.

There are several reasons why this glimpse of the Persian Empire and its interest in mining should be connected to the depiction of the Ptolemaic Empire in the Letter. First, Egypt and Persia were the two states that had been most instrumental in Jewish sufferings according to earlier Jewish texts. Take, perhaps most programmatically, the narrative of Ezra-Nehemiah. The book rehearses the Hebrews' descent from Egypt and Moses' giving of the Law at Sinai with its own story of the Jews' return from the Babylonian captivity and Ezra's reading out of the Law to the people in Jerusalem (Neh 8:I-3). Second, the Letter explicitly sets out in an earlier section how the Ptolemaic enslavement of the Jews replayed the actions of earlier empires: Ptolemy I Soter's trafficking of Jewish bodies into Egypt follows on from those forced along 'with the

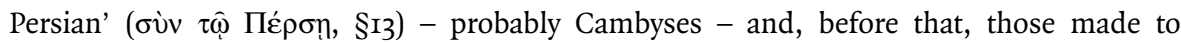

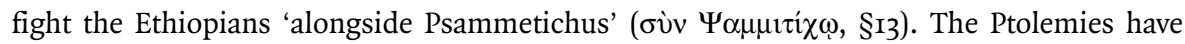
inherited both Persian and Egyptian imperial policies with respect to the Jews. Third, the language describing the Persian interest in mining echoes Ptolemy's plans for the table that precede Aristeas' description. Ptolemy follows the written prescriptions for the measurements of the table 'lest it become useless ( $\alpha \chi \alpha \eta \sigma \tau \sigma \varsigma)$ for the liturgy' (\$53), and instead all that 'he ought to have spent (' $\delta \varepsilon \varepsilon \delta \alpha \pi \alpha v \eta \theta \tilde{\eta} \nu \alpha l)$ on a larger construction' (\$72) he lavished on craftsmanship and on precious stones. The Persians do not commit

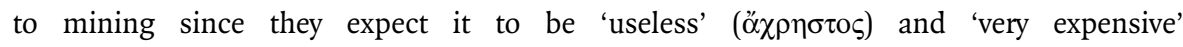

20 Comments of confusion include Meecham (I932) 4I, Hadas (I95I) I48 and now Wright (2015) 234: '[T] he reason for these two paragraphs on the mines of Arabia is not particularly clear.' 
( $\pi \mathrm{0} \lambda \nu \delta \alpha \dot{\alpha} \pi \alpha \nu \mathrm{s}$, §II9). Matters of return on expenditure are paramount for imperial economies of luxury goods and their use. In both cases, too, the course of action is influenced by Jewish responses to imperial inquiry: Ptolemy seeks confirmation whether his excessive table would be acceptable in Jerusalem (\$\$52-3), while those in charge of Judaea circulate misinformation in order to avoid the destruction of the land. In other words, underlying these two points of intercultural dialogue - bookending, in fact, the two sections of the Letter I have been examining - is a consistent image of the role luxury goods played as part of the operations of empire. This raises the question of just how different the Ptolemies and the Persians are, and of the shared imperial ideology that unites the construction and donation of extravagant gifts and the spoliation of the land's natural resources through mining.

The Ptolemies too, of course, were expansionist - Theocritus describes how

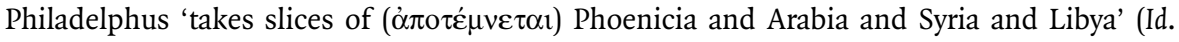
I7.86-7) - and they also exploited natural resources in their quest for precious materials and the promotion of a trade in luxury goods. Surviving evidence shows that they inherited and reorganised a pre-existing pharaonic system of gold mines in the central Eastern Desert of Egypt (between the Nile and the Red Sea). ${ }^{2 \mathrm{I}}$ There is also good evidence that precious stones such as amethyst and topaz were increasingly mined, and this may have been in response to royal tastes. ${ }^{22}$

Important for my purposes, however, are the literary responses to this historically attested mining. The opening section of the Milan papyrus of Posidippus, the so-called Lithika, presents an extended, multifaceted response to this material economy and luxury industry, celebrating the sourcing of precious stones and its Ptolemaic underwriting. The twenty epigrams dwell on the aesthetic qualities and value of various stones and metals.

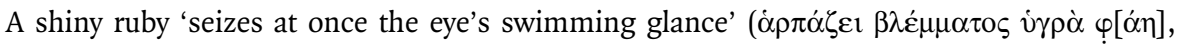
3.2 $\mathrm{AB}$ ); a carnelian 'defeats the rubies of India with beams of equal light' ( $\alpha \mu u \dot{v} v \varepsilon \alpha 1$

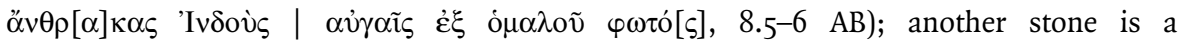

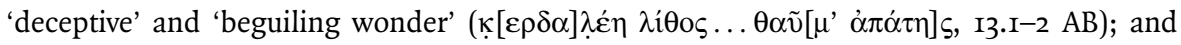
on an engraved draconitis stone 'you would not see any protrusions', which is why it is a

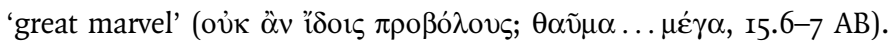

2I Klemm and Klemm (20I3) I2-I5 for the Ptolemaic evidence, 6I3 for spatial distribution, and 86, I60, 204, 2I2, 247, $25 \mathrm{I}$ and 263 for the presence of Ptolemaic forts. For further context cf. Ogden (I990) 39-57. Agatharchides - midsecond century (see below) - records that a high number of prisoners were sent to the gold mines to satisfy the labour required for extraction (23b-24b Burstein).

22 Archaeological and inscriptional evidence at Abu Diyeiba in the Eastern Desert attests to amethyst mining; cf. Harrell et al. (2006). See Shaw (2007) for the connection between gold and amethyst mining. If HE 44 GowPage (= Anth. Pal. 9.752), on an amethyst ring worn by a certain Cleopatra, refers to Alexander's sister, then that precious stone had already gained value by the early Ptolemaic period; cf. Gutzwiller (I995). The Topaz Islands, Agatharchides again records, were strictly controlled by the Ptolemies (84b Burstein, see below). According to King Juba of Mauretania, quoted by Pliny, Philadelphus' governor Philo presented topaz to his mother Berenice and he so admired it that enough was mined to fashion a statue to his wife Arsinoe (FGrH 275 F 34). 
The epigrams also focus on the extraction of the stones and material. Several come from a Persian context (4, 5, 8, II and $\mathrm{I} 3 \mathrm{AB}$ ); the draconitis is extracted from a snake's head (I5.I$2 \mathrm{AB}$ ); a magnetic stone is 'uprooted' from a mountain ( $\alpha \dot{\alpha} \varepsilon \rho \rho i \zeta \omega \sigma \varepsilon v, \mathrm{I} 7 . \mathrm{I} \mathrm{AB})$; and, in an epic take on the epigrammatic genre, Polyphemus 'breaks off' and hurls a stone into the sea $(\dot{\alpha} \pi[0 \kappa \lambda \dot{\alpha} \varsigma, 19.3 \mathrm{AB})$. However, Posidippus ends the Lithika with a prayer to Poseidon that he

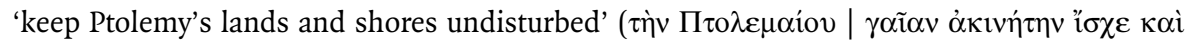
$\alpha i \gamma 1 \alpha \lambda o v ́ s, 20.5-6 \mathrm{AB})$. This appeal for geographical stability exposes Posidippus' double standards, or perhaps even his unawareness of such double standards when it comes to conceptualising how the economy of precious stones affects the land. ${ }^{23}$ While materials for adornment and display have been represented as torn up and transported from around the Mediterranean, Posidippus balances out this prospect with the concluding hope of territorial fixity and that Ptolemy's lands are not subject to that same disruption, displacement and despoliation.

The combined aesthetic value and movement of the stones presents a manifestly imperial dynamic in which natural products are gathered from elsewhere and assembled in various ways so as to bring about a striking visual effect. The wonder of a magnetic stone able to move iron ( $\mathrm{I} 7 \mathrm{AB}$ ), for example, finds a monumental, propagandist parallel in the projected yet unfinished temple for Arsinoe II by Timochares. Within the magnetic stone structure of the temple, an iron statue of the queen would 'seem to hang in the air' (pendere in aere uideretur, Pliny, HN 34-I48). The collective picture of precious objects from the known world gravitating towards a centre again underscores - not unlike the procession and pavilion - the Ptolemaic power to fashion wonder by concentrating a range of natural products into a small compass for display within the court. ${ }^{24}$

It is further significant that a quarter of the epigrams describe Persian materials and luxury: 4 and $8 \mathrm{AB}$ depict a gem with an image of Darius; Timanthes has carved lapis lazuli, a 'Persian half-stone', for Nicaea (5.2 AB); II AB describes a Persian shell; and I3 $A B$ depicts an engraved Persian lion. While there are other imperial models present in the Lithika - e.g. Polycrates in $9 \mathrm{AB}$ - this suggests that the Ptolemaic collection is in part inheriting Persian material. ${ }^{25}$ It is evident that there was both a traffic in artistic style between Greece and Persia in the Classical period and that this trend was accelerated following Alexander's conquest of Persia, which 'flooded the market with precious stones' ${ }^{26}$ Many luxury Persian items continued to find their way into Greek temples well into the Hellenistic period. ${ }^{27}$ The Lithika thus responds to a broader historical trend,

23 On whether $20 \mathrm{AB}$ is really part of $\mathrm{Ig} \mathrm{AB}$, see e.g. Bastianini and Austin (2002) 42; Gasser (2015) Io6-7. This does not, in any case, affect my interpretation.

24 On the Lithika's geopolitics cf. Bing (2005) and Prioux (2008) 177-200; for the emphasis on wonder cf. Elsner (2014), Gasser (2015) 23 and Lightfoot (2021) 38-4I; for the idea of display cf. Kuttner (2005).

25 Cf. Prioux (2008) 179-84.

26 For the Persian influence on Greek style see Miller (1997), and on gems specifically Boardman (200I) ch. 6 for the so-called 'Greco-Persian style'. The early Hellenistic development of Persian themes in Ptolemaic cameos is discussed in Kosmetatou (2003), from which the quotation derives (p. 36). 
advertising that Alexandrian aesthetics build upon materials from the empire that they conquered. $^{28}$

I take the author of the Letter to be appealing to this pre-existing theme of Ptolemaic propaganda by referencing Persian mining together with the account of Ptolemy's plan for the gifts and their highly wrought stonework. Posidippus' collection presents positively the extraction of stones from the earth for the purpose of creating exquisite and costly works of art, however, in the Letter the destruction of the land and its alienation from those who live

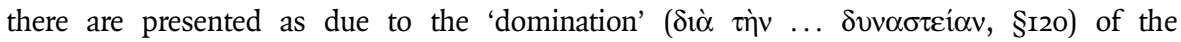
Persians. The focus in that short account certainly places the imperial mining in a negative light.

While Posidippus takes a pro-Ptolemaic stance, there also survive works closer in time to the Letter that are much more aware of the real costs of Ptolemaic mining. The Alexandrian historian Agatharchides, writing a few decades (at most) before the Letter, provides testimony to the resources expended on, and Ptolemaic control over, the mining of precious stones and he makes clear the exploitation it involved. ${ }^{29} \mathrm{He}$ describes the terrible conditions and

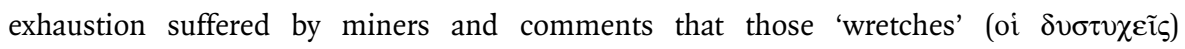

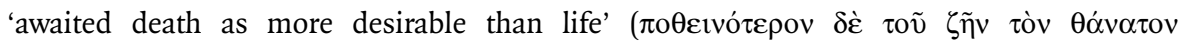
$\pi \rho 0 \sigma \delta \varepsilon \dot{z} \chi v \tau \alpha$ l, Diod. Sic. 3.13.3). So eager were the kings of Egypt to increase the labour supply that even those accused unjustly were sent to the mines, sometimes with their entire family $(3.12 .2-3)$. A similar treatment met those guarding the Topaz Islands. So strict was Ptolemaic control over them that, in order to prevent the theft of the precious stone, no others were allowed on the island, not even to supply the guards with food and comforts; instead, food was delivered by boat on a semi-regular basis with delays reducing the inhabitant guards to despair (3.39.6-7). Nor were humans the only casualties. The Ptolemies' vigorous attempts to take possession of the islands meant not only preventing all forms of agriculture but also ridding an entire island of snakes (from which it had derived its name, 'Snake Island') (84b Burstein). As Pliny would later so pointedly and stoically put it, luxury comes at the cost of the damage done to the earth and to Nature by the invasive process of mining: 'we drag out her entrails, searching for a gem to be worn on the finger' (HN 2.158). For Agatharchides, the nature of these mined precious metals is complex indeed and 'costly' in a number of senses: the great number of bodies lost to mining gold show that its 'use lies between pleasure and pain' (

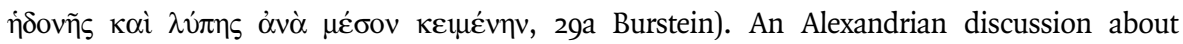
precious stones and their extraction contemporary with the Letter is cognizant of this conflict in consumption: valuable and marvellous though they be, they come at the cost of both lives and the land.

Contemporary Greek Jewish literature, moreover, knew that the Egyptian Empire was well versed at exploiting its subjects, and particularly its Jewish subjects. The Israelites'

28 Cf. Müller (2015) I4I-7. Petrovic (2014) has proposed that the Lithika's geopolitics of materials gravitating towards the Ptolemaic court was influenced by an Achaemenid discourse of imperial power. The collection would then present the Ptolemies as heirs to an ideology of luxury acquisition as well as of the very items themselves.

29 Burstein (1989) I3-I7 places Agatharchides' On the Erythraean Sea at around I45 BCE. 
sojourn in Egypt is directly connected to their forced labour as required for imperial manufacture and construction, an association already latent in Deuteronomy's metaphorical description of the Lord bringing them 'out of Egypt, out of the iron

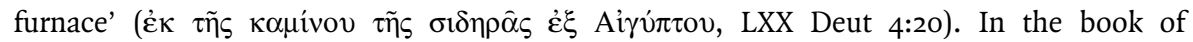
Judith, the advisor of the Persian general Holophernes, Achior, recounts to him the story of the Israelites in Egypt: 'and the king of Egypt rose against them and tricked them into

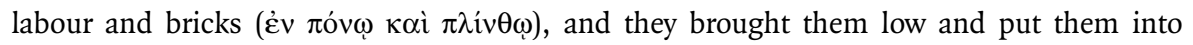

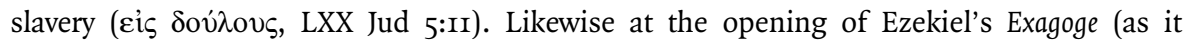
survives today), the play contextualises the current predicament of the Israelites, whose people the king of Egypt 'afflicted with brickwork and the heavy labour of construction'

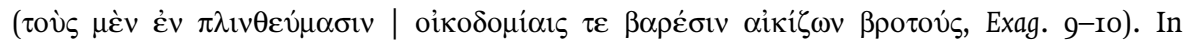
both cases the servitude comes about because of pharaoh's deviousness and is aimed at reducing their large populace (cf. LXX Jud 5:10; Exag.7-8). Works roughly contemporary with the Letter expose what an Egyptian product could in fact entail for the Jewish people. The grand, scaled-up constructions of Egypt were historically implicated in the reduction of the Jewish population.

Posidippus celebrates the pull of Ptolemaic power and its ability to tear materials from the earth to fashion wondrous trinkets for display, but later Alexandrian literature was fully aware of the mechanisms by which such materials really made it to the Ptolemaic court. And Alexandrian Jews would have understood more than most the suffering and domination that Ptolemaic Egyptian constructions could engender. The mention of the Persians' mining aspirations in the Letter thus reframes the earlier Ptolemaic construction of the gifts. It points to a common imperial system where artistic value and visual effect are undergirded by imperial encroachment and by the exploitation of people and nature. The gems that end up on the gifts and the gold and silver bowls are in reality the result of a process of conquering and deracinating the land of its products. The table's ability to simulate nature through art initially appears to index an interest in naturalism and verisimilitude. Yet Aristeas' vision of the cultivation of Judaea, set in stark contrast to the gifts, ultimately uncovers the operations that make such artworks possible. The gifts require a high concentration of labour focused on a single object, a concentration which also led to the overpopulation of Alexandria. The labour of the Jewish farmers matches up to the fertility of the country in order to provide for its inhabitants and to enable worship in the Temple in a balanced way, while the labour of the Alexandrian artists produces a mere simulation of natural fecundity. And the objects are doubly perverted in that they not only offer a mere semblance of nature, but their production from precious stones and metals entails a destruction of the natural landscape and having designs on the resources of other countries. Accompanying the naturalism of Ptolemy's gifts, in other words, is an imperialism over nature itself.

\section{Conclusion: scrutinising imperial products}

I have argued that juxtaposing these two so-called 'digressions' in the Letter allows one to view a rare case where an imperial subject both describes and critiques the art of empire, 
uncovering the political domination, the economic disequilibrium and natural destruction that go into the overlord's opulence. And the vision of these gifts is in its essence culturally bifocal. The author is Alexandrian in his knowing use of ecphrastic tropes and engagement with traditions of Ptolemaic propaganda such as the due proportion of the capital, the fertility of the land and the conspicuous display of finely worked materials. But it is in this erudition that their Jewishness also inheres. For what is recognisably Alexandrian is nevertheless turned on its head and presented from a Jewish perspective: Judaea succeeds where Alexandrian agricultural administration and fecundity fails, and the precious gems on Ptolemy's gifts appear only a stone's throw away from the imperial appropriation and exploitation of the Judaean land. This is a sophisticated description of the Alexandrian gifts that carefully frames its presentation of the artworks. Not only does the Letter exhibit a keen art-critical eye - something not typically afforded to ancient Jewish literature by modern scholars - but it also demonstrates an acute awareness of the political processes and power moves that fashion Ptolemaic aesthetics on the level of both visual representation and raw material. Taken together, these sections in the Letter diagnose the imperial ideology informing Alexandrian art.

This attitude towards Alexandrian art has important ramifications for the central narrative of the translation of the Hebrew Torah into Greek. Ptolemy has the gifts made in order for them to be used as part of the liturgy in the Jerusalem Temple, but as part of a diplomatic exchange they are also commensurate with what he is asking for. Ptolemy is thus lent in return a Hebrew copy of the Torah and seventy-two translators in order to produce a Greek version of the Jewish scriptures which will be used in the ritual activities of Greek-speaking Jews. In terms of their value and their construction in Alexandria under Ptolemy's authority, then, the gifts parallel the soon-to-be-created Septuagint. In modern scholarship, the diplomatic interactions traced out tend to be interpreted, if at all, as running smoothly: the translation is a mutually beneficial project in which both parties are equally invested..$^{\circ}$ By contrast, what has emerged from this analysis is the Letter's awareness of the deceptive and appropriative nature of Ptolemaic projects and the imperialism that underlies their construction of cultural objects. If this is the real nature of the material gifts that Ptolemy wishes to be used as part of the Jewish liturgy, then it should raise serious questions and considerable anxiety concerning the Alexandrian creation of the Septuagint. Before the Torah scrolls have even arrived in Alexandria from Jerusalem, Aristeas' description of the gifts and account of the Temple and Judaea point to the imperial ideology that will be brought to bear upon the reproduction of the most important Jewish liturgical work, the Law itself.

\section{Works cited}

Barclay, J. M. G. (1996) Jews in the Mediterranean diaspora: from Alexander to Trajan (323 BCE - 117 CE), Edinburgh.

Bastianini, G. and C. Austin (2002) Posidippi Pellaei quae supersunt omnia, Milan.

30 E.g. Barclay (I996) I4I and Gruen (2002) 2 I4. 
Bing, P. (2005) 'The politics and poetics of geography in the Milan Posidippus, section one: On stones

(AB I-20)', in K. J. Gutzwiller (ed.), The New Posidippus: a Hellenistic poetry book, Oxford, II9-40.

Boardman, J. (200I) Greek gems and finger rings: early Bronze Age to late Classical, 2nd edn, London.

Burstein, S. M. (1989) Agatharchides of Cnidus: On the Erythraean Sea, London.

Clarysse, W. and D. J. Thompson (2006) Counting the people in Hellenistic Egypt, 2 vols., Cambridge.

von Ehrenkrook, J. (20II) Sculpting idolatry in Flavian Rome: (an)iconic rhetoric in the writings of Flavius Josephus, Atlanta.

Elsner, J. (2014) 'Lithic poetics: Posidippus and his stones', Ramus 43, 152-72.

Février, J. G. (1924) La date, la composition et les sources de la Lettre d'Aristée à Philocrate, Paris.

Fine, S. (2005) Art and Judaism in the Greco-Roman world: toward a new Jewish archaeology, Cambridge.

Gasser, A.-M. (2015) 'Lithika', in B. Seidensticker, A. Stähli, A. Wessels and F. Angiò (eds.), Der neue Poseidipp: Text - Übersetzung - Kommentar, Darmstadt, I9-III.

Goldhill, S. (1994) 'The naive and knowing eye: ecphrasis and the culture of viewing in the Hellenistic period', in S. Goldhill and R. Osborne (eds.), Art and text in ancient Greek culture, Cambridge, 197-223.

Gow, A. S. F. (1952) Theocritus, 2 vols., Cambridge.

Gruen, E. S. (2002) Diaspora: Jews amidst Greeks and Romans, Cambridge, MA.

Gutmann, J. (I96I) 'The "second commandment" and the image in Judaism', Hebrew Union College Annual 32, I6I-74.

(I977) 'Deuteronomy: religious reformation or iconoclastic revolution?', in J. Gutmann (ed.), The image and the word: confrontations in Judaism, Christianity and Islam, Missoula, MT, 5-25.

Gutzwiller, K. J. (1995) 'Cleopatra's ring', GRBS 36, 383-98.

Hachlili, R. (I988) Ancient Jewish art and archaeology in the land of Israel, Leiden.

Hadas, M. (I95I) Aristeas to Philocrates: Letter of Aristeas, New York.

Hanhart, R. and A. Rahlfs (eds.) (2006) Septuaginta: id est Vetus Testamentum Graece iuxta lxx interpretes, Stuttgart.

Harrell, J. A., S. E. Sidebotham, R. S. Bagnall, S. Marchand, J. E. Gates and J.-L. Rivard (2006) 'The Ptolemaic to Early Roman amethyst quarry at Abu Diyeiba in Egypt's eastern desert', BIAO Io6, I27-62.

Heath, J. (2013) 'Greek and Jewish visual piety: Ptolemy's gifts in the Letter of Aristeas', in S. Pearce (ed.), The image and its prohibition in Jewish antiquity, Yarnton, 38-48.

Honigman, S. (2003a) 'Politeuma and ethnicity in Ptolemaic and Roman Egypt', Ancient Society 33, 6I-I02.

(2003b) The Septuagint and Homeric scholarship in Alexandria: a study in the narrative of the Letter of Aristeas, London.

(2016) 'The Ptolemaic and Roman definitions of social categories and the evolution of Judaean communal identity in Egypt', in Y. Furstenburg (ed.), Jewish and Christian communal identities in the Roman world, Leiden, 25-74.

Hunter, R. (2003) Theocritus: Encomium of Ptolemy Philadelphus, Berkeley, CA.

(20II) 'The Letter of Aristeas', in A. Erskine, L. Llewellyn-Jones and S. Winder (eds.), Creating a Hellenistic world, Swansea, 47-6o.

Jellicoe, S. (1968) The Septuagint and modern study, Oxford.

Keyser, P.T. (2014) 'Kallixeinos of Rhodes (627)', in I. Worthington (ed.) Brill's New Jacoby, online at: https://referenceworks.brillonline.com/entries/brill-s-new-jacoby/kallixeinos-of-rhodes-627-a627?s. num=o\&s.f.s2_parent=s.f.cluster.Jacoby+Online\&s.q=Kallixeinos.

Klemm, D. D. and R. Klemm (2013) Gold and gold mining in ancient Egypt and Nubia: geoarchaeology of the ancient gold mining sites in the Egyptian and Sudanese eastern deserts, Berlin.

Kosmetatou, E. (2003) 'Poseidippos, "Epigr." 8 AB and early Ptolemaic cameos', ZPE I42, 35-42.

(2004) “"Persian” objects in Classical and early Hellenistic inventory lists', MH 6I, I39-70.

Kuttner, A. (2005) 'Cabinet fit for a queen: the $\Lambda \mathrm{\imath} \theta \mathrm{\imath} \alpha$ ' as Posidippus' gem museum', in K. J. Gutzwiller (ed.), The New Posidippus: a Hellenistic poetry book, Oxford, I4I-63.

Levine, L. I. (2012) Visual Judaism in late antiquity: historical contexts of Jewish art, New Haven, CT. 
Lightfoot, J. (202I) Wonder and the marvellous from Homer to the Hellenistic world, Cambridge.

Männlein-Robert, I. (2007) Stimme, Schrift und Bild: zum Verhältnis der Künste in der hellenistischen Dichtung, Heidelberg.

Meecham, H. G. (I932) The oldest version of the Bible: 'Aristeas' on its traditional origin, London.

Miller, M. C. (1997) Athens and Persia in the fifth century BC: a study in cultural receptivity, Cambridge.

Modrzejewski, J. (I993) 'How to be a Jew in Hellenistic Egypt?', in S. J. Cohen and E. S. Freirichs (eds.), Diasporas in antiquity, Atlanta, 65-92.

(1997) The Jews of Egypt: from Rameses II to Emperor Hadrian, tr. R. Cornman, Philadelphia, PA.

Moore, S. (2015) Jewish ethnic identity and relations in Hellenistic Egypt: with walls of iron?, Leiden.

Müller, S. (2015) 'Poseidippos of Pella and the memory of Alexander's campaigns at the Ptolemaic court', in S. Müller, W. Heckel and G. Wrightson (eds.), The many faces of war in the ancient world, Newcastle, $135-65$.

Neis, R. (2013) The sense of sight in rabbinic culture: Jewish ways of seeing in late antiquity, Cambridge.

Ogden, J. M. (I990) 'Gold jewellery in Ptolemaic, Roman and Byzantine Egypt', PhD thesis, Durham University.

Pearce, S. (ed.) (2013) The image and its prohibition in Jewish antiquity, Yarnton.

Pelletier, A. (1962) Lettre d'Aristée à Philocrate, Paris.

Petrovic, I. (2014) 'Posidippus and Achaemenid royal propaganda', in R. Hunter, A. Rengakos and E. Sistakou (eds.), Hellenistic studies at a crossroads: exploring texts, contexts and metatexts, Berlin, 273-30o.

Pietersma, A. and B. G. Wright (eds.) (2007) A new English translation of the Septuagint: and the other Greek translations traditionally included under that title, New York.

Platt, V. (2009) 'Where the wild things are: locating the marvellous in Augustan wall painting', in P. Hardie (ed.), Paradox and the marvellous in Augustan literature and culture, Oxford, 4I-74.

Pollitt, J.J. (1974) The ancient view of Greek art: criticism, history, and terminology, New Haven, CT.

Prioux, É. (2008) Petits musées en vers: épigramme et discours sur les collections antiques, Paris.

Rice, E. E. (1983) The grand procession of Ptolemy Philadelphus, Oxford.

Segré, A. (1944) 'The status of the Jews in Ptolemaic and Roman Egypt: new light from the papyri', Jewish Social Studies 6, 375-400.

Shaw, I. (2007) 'Late Roman amethyst and gold mining at Wadi el-Hudi', in K. M. Szpakowska and T. Schneider (eds.), Egyptian stories: a British Egyptological tribute to Alan B. Lloyd on the occasion of his retirement, Münster, 319-28.

Squire, M. (2010) 'Making Myron's cow moo? Ecphrastic epigram and the poetics of simulation', AJPh I3I, 589-634.

Webster, T. B. L. (I967) Hellenistic art, London.

White, L. M. and G. A. Keddie (2018) Jewish fictional letters from Hellenistic Egypt: the Epistle of Aristeas and related literature, Atlanta.

Wright, B. G. (2015) The Letter of Aristeas: Aristeas to Philocrates or On the translation of the Law of the Jews, Berlin.

Zanker, G. (2004) Modes of viewing in Hellenistic poetry and art, Madison, WI. 